\title{
Analisis dan Desain Sistem Pendukung Keputusan Penilaian Kinerja Pegawai dengan Metode Analytical Hierarchy Process (AHP)
}

\author{
Rohmat Taufiq ${ }^{1}$, Sulkhan ${ }^{2}$, Yulianti ${ }^{3}$, Aries Saifudin ${ }^{4}$ \\ ${ }^{1}$ Teknik Informatika, University of Muhammadiyah Tangerang, Jalan Perintis Kemerdekaan I \\ Babakan No.33, RT.007/RW.003, Cikokol, Kec. Tangerang, Kota Tangerang, Banten 15118 \\ ${ }^{2}$ Teknk Industri, Universitas Buddhi Dharma, Jalan Jl. Imam Bonjol No.41, Karawaci, Kec. \\ Karawaci, Kota Tangerang, Banten 15115 \\ ${ }^{3,4}$ Teknik Informatika, Universitas Pamulang, Serpong, Tangerang Selatan, Banten, Indonesia, \\ 15310 \\ e-mail: 'rohmat.taufiq@umt.ac.id; ${ }^{2}$ sulkhan.sulkhan@ubd.ac.id; ${ }^{3}$ yulianti@unpam.ac.id; \\ 4aries.saifudin@unpam.ac.id
}

Submitted Date: September $08^{\text {th }}, 2020$

Revised Date: September $28^{\text {th }}, 2020$
Reviewed Date: September 22 $2^{\text {nd }}, 2020$

Accepted Date: September 30 ${ }^{\text {th }}, 2020$

\begin{abstract}
The decision support system (DSS) for employee performance appraisal is a decision support system used in the employee performance appraisal process at PT. Surya Toto Tbk. Currently, the employee performance appraisal process is still done manually (paper based) so that the reports produced are not real time. From the existing problems, this research aims to analyze and design a decision support system according to the existing criteria using the Analytical Hierarchy Process (AHP) method with the aim of being able to be developed into a Web-based DSS. The method used begins with communication with management, especially the perpetrators of employee performance appraisals. Furthermore, planning, data collection process, analysis, design and finally making reports are carried out. The conclusion of this study provides a suggestion for the addition of subcriteria from the existing criteria. After calculating with AHP, the value that appears for the work outcome criteria (A) on the quantitative subcriteria A11 with a score of 0.123 , qualitative A12 with a score of 0.033 , delivery A13 with a score of 0.024 and Implementation of SOP A14 with a score of 0.018 . The score is for a very good value (BS).
\end{abstract}

Keyword: Analysis; Design; Decision Support System; Assessment; Employee Performance

\section{Abstrak}

Sistem pendukung keputusan (SPK) penilaian kinerja pegawai merupakan sebuah sistem pendukung keputusan yang digunakan dalam proses penilaian kinerja pegawai yang ada di PT. Surya Toto Tbk. Saat ini proses penilaian kinerja pegawai masih dilakukan secara manual (paper based) sehingga laporan yang dihasilkan belum real time. Dari permasalahan yang ada, peneltian ini bertujuan untuk menganalisis dan mendesain sistem pendukung keputusan sesuai kriteria yang ada tersebut dengan menggunakan metode Analytical Hierarchy Process (AHP) dengan tujuan bisa dikembangkan ke dalam SPK berbasis Web. Metode yang dilakukan dimula dari komunikasi dengan pihak manajemen khususnya pelaku penilaian kinerja pegawai. Selanjutnya dilakukan perencanaan, proses pengumpulan data, analisis, desain dan yang terakhir pembuatan laporan. Kesimpulan dari penelitian ini memberikan usulan untuk penambahan subkriteria dari kriteria sebelumnya yang sudah ada. Setelah dilakukan penghitungan dengan AHP maka nilai yang muncul untuk kriteria hasil kerja (A) pada subkriteria kuantitatif A11 dengan skor 0.123, kualitatif A12 dengan skor 0.033, delivery A13 dengan skor 0.024dan Pelaksanaan SOP A14 dengan skor 0.018. Skor tersebut untuk nilai Baik Sekali (BS).

Keyword: Analisis; Desain; Sistem Pendukung Keputusan; Penilaian; Kinerja Pegawai 


\section{Pendahuluan}

Kebutuhan hidup kita sehari-hari bisa dikatakan teknologi informasi menjadi paling penting, itu dikarenakan banyak transaksi yang dilakukan menggunakan web based. Teknologi Informai menjadi penentu dalam memenangkan persaingan antar perusahaan karena dengan teknologi informasi mampu memberikan proses dan laporan seperti keuangan, kepegawaian, aplikasi absensi dan lainnya dengan cepat dan tepat. Dengan mengaplikasikan teknologi informasi berbasis web maka akan memberikan kemudahan bagi pegawai karena dinilai lebih efektif dan efisien.

Revolusi sebuah sistem informasi sudah didapatkan dari penggabungan antara teknologi komputer dengan telekomunikasi, sudah tidak bisa dipungkiri lagi bahwa teknologi menjadi andalam bagi perusahaan untuk meningkatkan produktivitas.

Secara umum sebuah teknologi informasi memberikan keuntungan bagi perusahaan dengan kemampuannya mengubah proses manual menjadi otomatis, waktu yang diperlukan untuk mengerjakan tugas lebih cepat, menghemat biaya, sistem dapat terintegrasi pada semua department dan pengambilan keputusan menjadi lebih cepat.

Dalam proses pengambilan keputusan secara cepat dan tepat sudah pasti dibutuhkan sebuah sistem pendukung keputusan dengan menggunakan metode yang sesuai bagi perusahaan. Ada banyak jenis sistem pendukung keputusan yang ada di perusahaan, penelitian ini membahas tentang sistem pendukung keputusan penilaian kinerja pegawai yang dilakukan di PT. Surya Toto Indonesia Tbk.

PT Surya Toto Indonesia, Tbk merupakan perseroan terbatas yang menghasilkan sanitary dan fitting. Beberapa produk dari perusahaan ini yang lebih familier bagi masyarakat seperti: keran air, tempat sabun, tempat tisu, gantungan handuk, dan kloset. PT Surya Toto Indonesia, Tbk berdiri pada tanggal 11 Juli 1977 yang berkantor pusat di Jl. Tomang Raya No. 18 Jakarta.

Tepatnya pada tanggal 26 Oktober 1978 dilakukan pendaftaran di di Kantor Pengadilan Negeri Jakarta sebagai perseroan terbatas Surya Toto, kemudian pada tanggal 21 November 1978 diumumkan dalam berita Negara Republik Indonesia. Pada bulan Februari 1978, PT Surya Toto Indonesia, Tbk memiliki kapasitas produksi 1.027.080 buah pertahundan jumlah karyawan sebanyak 2.600 orang. Luas area pabrik di daerah serpong adalah 5,8 hektar. Pada tahun 1994, selanjutnya perusahaan ini mendapatkan sertifikat internasional dari Jepang yang Namanya JIS (Japan industrial Standart) sehingga kualitas produk yang dihasilkan oleh perusahaan ini kualitasnya semakin terjamin.

Tempat penelitian ini dilakukan di PT. Surya Toto yang berada di Jl. Jl. MH. Thamrin KM 7 Desa Pakulonan, RT.004/RW.002, Panunggangan, Kec. Pinang, Kota Tangerang, Banten 15325. Dengan jumlah karyawan sebanyak kurang lebih 1.171 karyawan pada tahun 2020. Dengan jumlah karyawan sebanyak itu sudah tentu untuk melakukan proses penilaian dibutuhkan sebuah sistem pendukung keputusan berbasis web sehingga informasi berkenaan dengan penilaian kinerja yang dihasilkan menjadi lebih akurat, relevan, tepat waktu dan lengkap.

Sistem pendukung keputusan penilaian kinerja pegawai merupakan sebuah sistem yang digunakan untuk proses penilaian kinerja pegawai pada PT. Surya Toto Indonesia Tbk. Saat ini proses penilaian kinerja pegawai masih dilakukan secara manual (paper based) sehingga laporan yang dihasilkan belum real time. Kriteria yang digunakan: hasil kerja, penguasaan kerja, sikap kerja, disiplin dan faktor penunjang. Dimana masing-masing kriteria tersebut memiliki subkriteria yang jumlahnya berbeda-beda.

Peneltian ini bertujuan untuk menganalisis dan mendesain sistem pendukung keputusan sesuai kriteria yang ada tersebut dengan menggunakan metode Analytical Hierarchy Process (AHP). Selain mendesain juga membandingkan kecepatan dan ketepatan penilaian yang dilakukan dengan menggunakan metode AHP.

\section{Landasan Teori}

Pengertian Sistem Pendukung Keputusan (SPK) sudah ada di tahun 1970an yang di definisikan oleh Little dalam Turban, Aronson dan Liang (2005) menjelaskan bahwa SPK merupakan seperangkat prosedur berbasis model yang berfungsi melakukan proses merubah data dan penilaian untuk membantu seorang manajer untuk proses pengambilan keputusannya. Menurut Brien 2010 dalam Taufiq (2018) Sistem Pendukung Keputusan (SPK) merupakan sebuah sistem informasi berbasis komputer yang memberikan informasi yang sifatnya interaktif untuk manajer dan pelaku bisnis professional selama proses pengambilan 
keputusan. SPK memiliki komponen manajemen model, manajemen data dan manajemen user interface (Haag dan Cummings, 2013). Menurut Surbakti dalam Septarini (2017) banyak definisi yang secara kalimat tidak sama namun mengandung makna yang hampir mirip saslah sastu definisi menjelaskan bahwa pendukung keputusan merupakan sebuah sistem computer based yang memiliki sifat interaktif sehingga membantu bagian pengambil kebijakan dalamm memanfaatkan data dan model untuk membantu menemukan solusi dari segala masalah-masalah yang tidak terstruktur.

Banyak penelitian yang membahass tentang sistem pendukung keputusan dengan menggunakan metode AHP. Sebuah pengambilan keputusan pada hakikatnya harus memiliki beberapa alternatif. Kunci utama dari AHP adalah sebuah hierarki yang berfungsi untuk memudahkan menentukan kriteria dan subkriteria. Dengan hierarki yang sudah di bangun maka suatu masalah yang besar dan masalah yang tidak terstruktur mampu di pecahkan dengan sangat mudah dengan menggunakan hierarki (Taufiq \& Fahrozi., 2017). Taufiq dan Sugiharto (2011) menyimpulkan bahwa sistem pendukung keputusan dengan multiple criteria memberikan dampak positif bagi instansi, guna mempercepat dan meningkatkan akurasi dalam proses penilaian kinerja karyawan. Sebuah sistem yang sudah dibangun akan mampu Sistem yang dibangun mampu mendapatkan hasil perhitungan secara otomatis yang sama dengan dengan hasil perhitungan yang dilakukan secara manual. Besar harapan bahwa dengan sistem yang sudah dibangun mampu mendukung pimpinan dalam melakukan proses pengambilan keputusan secara sangat objektif, efektif dan efisien (Saefudin dan Wahyuningsih, 2014). Kesimpulan dari sebuah SPK penilaian kinerja guru mengatakan bahwasanya SPK dengan menggunakan metode AHP mampu menyelesaikan permasalahan dalam melakukan proses penilaian kinerja guru di SD Negeri Mohammad Toha (Mufizar dkk, 2015). Kriteria yang yang digunakan dalam proses perhitungan adalah kehadiran dosen dengan nilai 0.6169 (61\%), kemudian pengumpulan nilai 0.2703 (27\%), keterlambatan masuk pbm 0.0564 (5\%) dan kecepatan mengakhiri pbm 0.0564 (5\%) (Sari dan Saleh, 2014).

Dalam penelitian yang lain juga menyatakan bahwa sistem pendukung keputusan pemilihan jurusan membantu dalam pengambilan keputusan dalam penentuan kelas siswa yang disesuaikan dengan kemampuannya (Taufiq dan Mustofa,
2017). Sistem Pendukung Keputusan mampu membantu permasalahan yang ada karena bobot nilai yang digunakan, proses penerimaan beasiswa bisa lebih efektif dan optimal (Liesnaningsih dkk, 2020). Selain itu SPK mempermudah dalam menentukan Layak atau Tidaknya pegawai mendapatkan kenaikan pangkat dan mempermudah dalam proses pembuatan laporan (Suherdi dkk, 2018). SPK juga berfungsi sebagai fasilitas penunjang untuk menghitung kinerja pegawai (Hardianti dkk, 2017). Metode AHP membuktikan bagus digunakan untuk penilaian kompetensi soft skill karyawan (Umar, Fadlil dan Yuminah, 2018). Dengan pengembangan sistem informasi berbasis web memudahkan pengguna dalam melakukan kegiatannya (Taufiq, 2020).

\section{Metode Penelitian}

Dalam metode penelitian ini yang dilakukan terdapat 6 langkah yang terdiri dari komunikasi, rencana, pengumpulan data, analisis, desan dan pembuatan laporan.

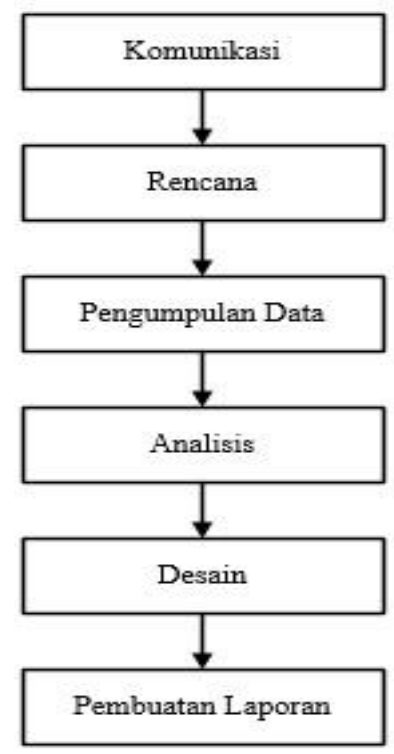

Gambar 1 Metode Penelitian

Komunikasi merupakan langkah awal dalam penelitian ini, yang dilakukkan dalam komunikasi untuk mengetahui sistem pendukung keputusan di perusahaan, mengetahui kriteria yang digunakan dan masalah tentang proses penilaian kinerja pegawai. Langkah selanjutnya yaitu rencana, yang dilakukan membuat perencanaan bagaimana cara menganalisis dan mendesain, alat apa yang dibutuhkan dan berapa lama waktu yang akan dipergunakan. 
Langkah ketiga yaitu pengumpulan data, yang dilakukan dengan cara wawancara, observasi dan literatur. Langkah keempat yaitu analisis, yang dilakukan dalam analisis yaitu mengetahui bagaimana proses yang berjalan, menghitung kriteria dengan bobot yang sudah ditentukan dengan menggunakan metode AHP. Langkah kelima yaitu desain, yang dilakukan membuat desain logic dengan menggunakan Unified Modelling Language (UML) dan desain fisik dengan menggambar tampilan form yang diusulkan.

Langkah yang terakhir yaitu membuat laporan akhir yang nantinya akan diberikan kepada manajemen PT. Surya Toto Tbk. Dari laporan tersebut harapan kedepannya bisa dilanjutkan ke dalam aplikasi berbasis web.

\section{Analisis dan Desain}

\subsection{Komunikasi}

Komunikasi yang dilakukan dalam langkah ini mendapatkan sistem yang berjalan dan beberapa kendala yang ada dengan menggunakan sistem ini yaitu laporan belum real time saat dibutuhkan dan proses yang dilakukan masih memakan waktu yang lama. Sehingga perusahaan mengharapkan sebuah desain yang bagus untuk dipelajari terlebih dahulu dan apabila desain sudah sesuai dengan yang diharapkan selanjutnya akan dikembangkan ke dalam sistem berbasis web.

\subsection{Rencana}

Dalam rencana ini terdapat bebepa hal yang akan dijadikan sebagai acuan dalam melakukan analisis, yaitu kriteria diberikan bobot yang sesuai, dilakukan perhitungan dengan menggunakan metode AHP, dibuat sebuah desain yang mudah digunakan, desain dibuat agar lebih fleksibel dalam menentukan kriteria, subkriteria dan botot. Sehingga jika ada perubahaan kriteria yang digunakan bisa berubah dengan mudah.

\subsection{Pengumpulan Data}

Data didapatkan melalui wawancara dan observasi langsung dengan hasil gambar dari sistem yang berjalan berupa flowchart, kriteria yang digunakan dan bobotnya, proses penilaian, evaluasi penilaian dan cara memutuskan dalam penilaian. Literatur dilakukan untuk mendapatkan teori-teori dari berbagai sumber baik buku, jurnal atau prosiding.

\subsection{Analisis \\ 4.4.1 Sistem yang berjalan}

Langkah yang dilakukan pada saat ini masih manual yang terdiri dari 8 langkah. Langkah pertama yaitu membuat pengajuan cetak form penilaian lebih awal yang selanjutnya dilakukan distribusi form yang sudah di cetak pada langkah pertama tersebut. Langkah ke-3 bagian Seksi melakkukan penilaian pegawai dengan cara mengisi form penilaian yang dilanjutkan dengan langkah ke-4 memberikan form yang sudah diisi tersebut kepada HRD.

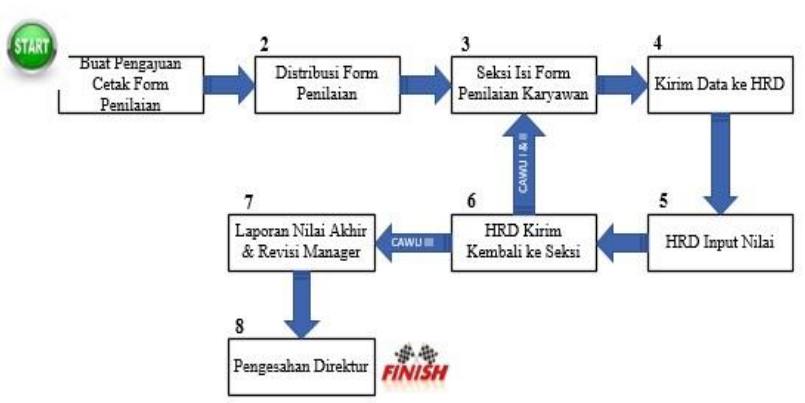

Gambar 2 Sistem yang Berjalan

Langkah ke-5 HRD melakukan input nilai menurut versi HRD sendiri. Selanjutnya pada langkah ke-6 HRD memberikan nilai tersebut kepada seksi untuk dilakukan perbaikan. Setelah langkah ke-6 dan kembali pada langkah ke-3, jika dianggap sudah clear maka dari langkah ke-6 dilanjutkan ke langkah ke-7 laporan nilai akhir dan revisi yang dilakukan oleh Manajer. Langkah yang terakhir setelah langkah ke-7 yaitu memberikan berkas penilaian tersebut kepada direktur untuk di sahkan.

\subsubsection{Kriteria dan SubKriteria}

Terdapat 5 kriteria yang digunakan dalam penialain kinerja karyawan. Dan masing-masing kriteria memiliki subkriteria yang jumlahnya berbeda-beda. Kelima kriteria dan subkriteria tersebut terdiri dari: Hasil Kerja (Kuantitas, Kualitas, Delivery, Pelaksanaan SOP), Penguasaan Kerja (Penguasaan Kerja), Sikap Kerja (Kerjasama, Moral dan Perilaku, Keuletan, Inisiatif), Disiplin (Absensi, Peringatan) dan Faktor Penunjang (5S dak K3, Inovasi).

\subsubsection{Perhitungan dengan AHP}

Ada beberapa langkah yang digunakan dalam perhitungan dengan menggunakan metode AHP yang terdiri dari:

1. Menentukan Hirarki Kriteria dan SubKriteria

Kriteria dan subkriteria yang digunakan dalam penilaian kinerja karyawan dijelaskan dengan Gambar 3 di bawah ini. 


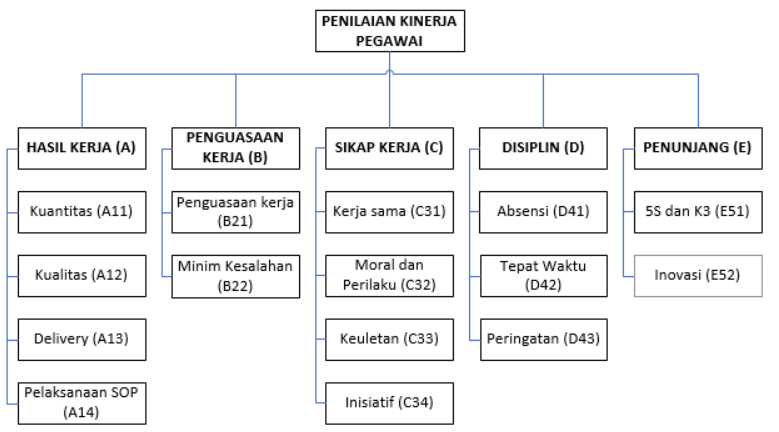

Gambar 3 Hirarki Kriteria dan SubKriteria

Gambar Hirarki kriteria dan subkriteria menjelaskan 5 kriteria yang digunakan. Kelima kriteria tersebut terdiri dari hasil kerja, penguasaan kerja, sikap kerja, disiplin dan penunjang. Masing-masing kriteria memiliki subkriteria yang jumlahnya berbeda-beda. Selain subkriteria yang menempel pada masing-masing kriteria tersebut masih terdapat subkriteria lagi, yaitu subkriteria Bobot yang terdiri dari Baik Sekali, Baik, Cukup, Kurang dan Kurang Sekali.

2. Memberikan bobot dan menghitung konsistensi rasio dengan Expert Choice 2000.

Dalam langkah ini yang dilakukan yaitu menentukan prioritas lokal. Dalam menentukan prioritas lokal dan terdapat konsistensi rasio dengan menggunakan software Expert Choice 2000.

a. Perbandingan berpasangan kriteria

Nilai perbandingan kriteria berikut, membandingkan antara kriteria yang digunakan hasil kerja, penguasaan kerja, sikap kerja, disiplin dan penunjang.

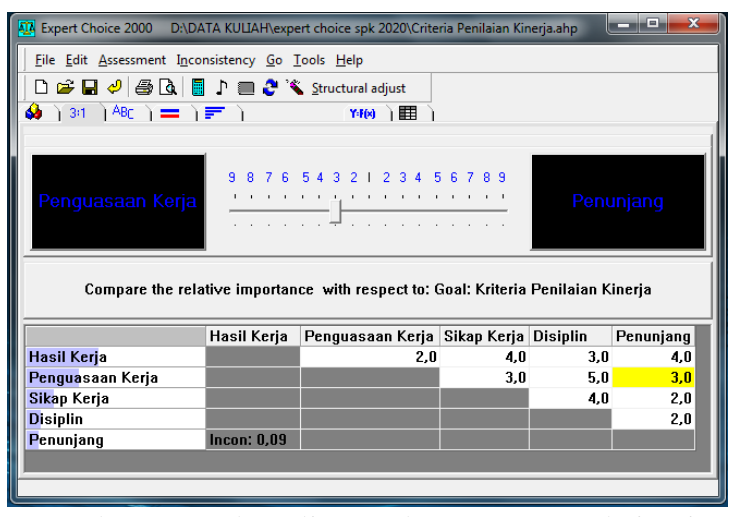

Gambar 4 Perbandingan berpasangan kriteria

Perbandingan berpasangan kriteria yang dilakukan pada Gambar 4, membandingkan bahwa hasil kerja memiliki kepentingan $2 \mathrm{x}$ dibandingkan dengan penguasaan kerja. Untuk perbandingan yang lainnya cara membacanya sama seperti itu. Dalam perhitungan tersebut konsistensi rasio yang didapat 0.09 artinya lebih kecil cari 0.1 , ini berarti perhitungan bisa diterima.

b. Perbandingan berpasangan subkriteria Hasil kerja

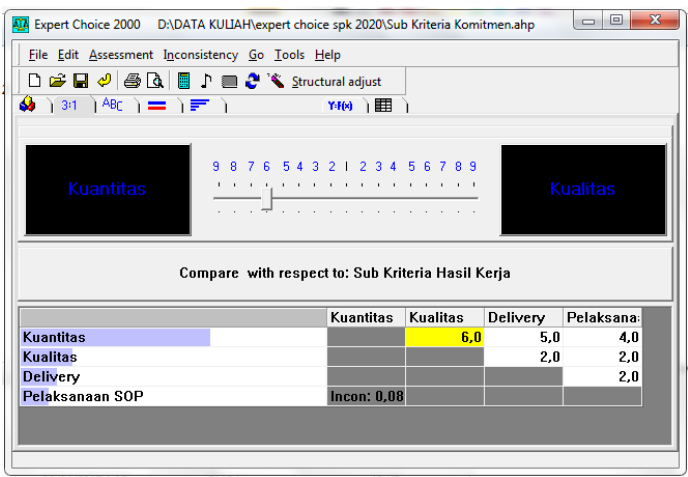

Gambar 5 Perbandingan berpasangan subkriteria Hasil Kerja

Dalam perbandingan berpasangan subkriteria hasil kerja di dapatkan nilai konsistensi rasio 0.08. Dengan nilai perbandingan bisa dilihat dalam Gambar 5 di atas.

c. Perbandingan berpasangan subkriteria Penguasaan kerja

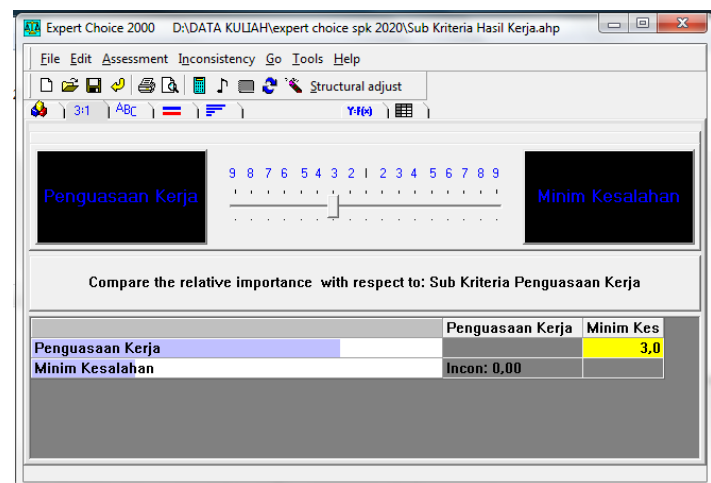

Gambar 6 Perbandingan berpasangan subkriteria penguasaan kerja

Perbandingan berpasangan subkriteria penguasaan kerja terdapat 2 kriteria. Nilai kepentingannya pengusaan kerja lebih penting 3x daripada minim kesalahan. Karena hanya 2 kriteria maka konsistensi rasio yang didapatkan 0.00 . 
d. Nilai perbandingan berpasangan subkriteria Sikap kerja

Nilai perbandingan berpasangan subkriteria sikap kerja menghasilkan nilai konsistensi rasio 0.06. Untuk perbandingan berpasangannya dijelaskan dengan Gambar 7 di bawah ini.

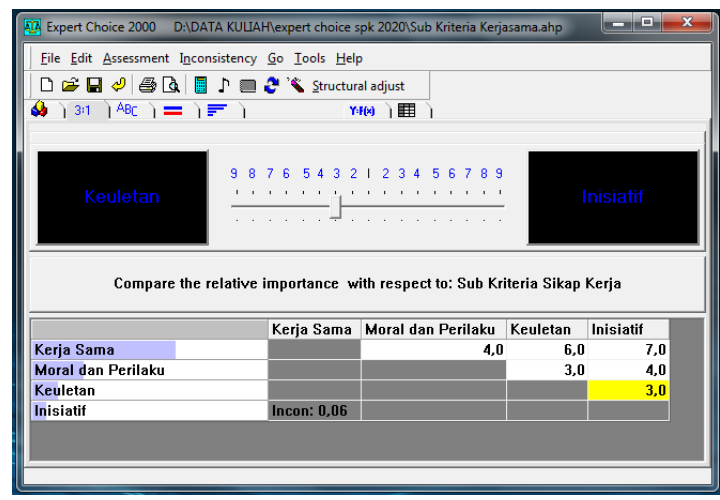

Gambar 7 Perbandingan berpasangan subkriteria sikap kerja

e. Perbandingan subkriteria Disiplin

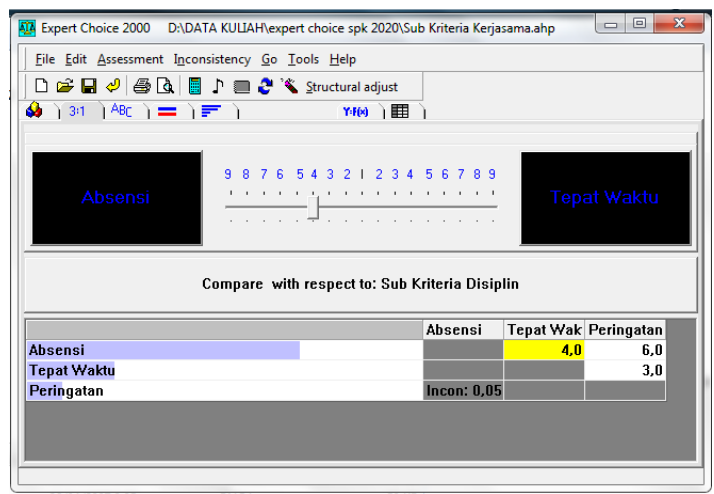

Gambar 8 Nilai perbandingan

Perbandingan

perbasangan subkriteria disiplin membandingkan 3 subkriteria yang terdiri dari Absensi, Tepat Waktu dan Peringatan. Dari angka kepentingan yang sudah dimasukkan seperti pada Gambar 8 di atas didapatkan nilai konsistensi rasio 0.05 .

f. Perbandingan berpasangan subkriteria Penunjang

Perbandingan perbandingan penunjuang pada Gambar 9 di atas membandingkan kepentingan antara 5S dan K3 dengan Inovasi. Karena hanya 2 subkriteria maka nilai konsistensi rasio yang didapatkan 0.00 .

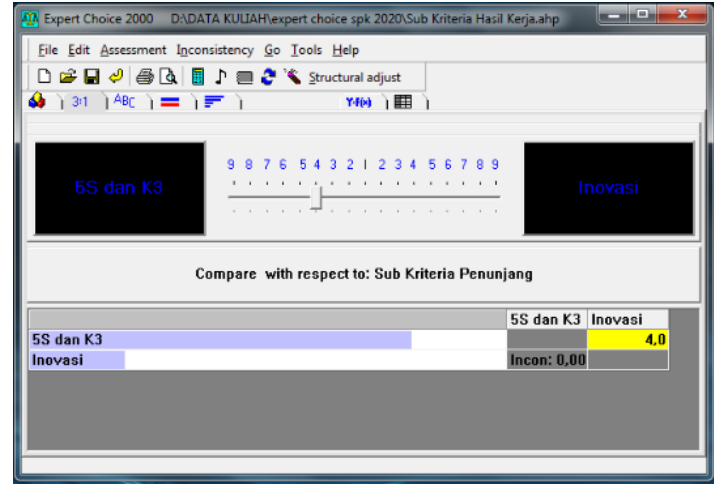

Gambar 9 Perbandigan perbasangan subkriteria penunjuang

g. Perbandingan subkriteria Bobot

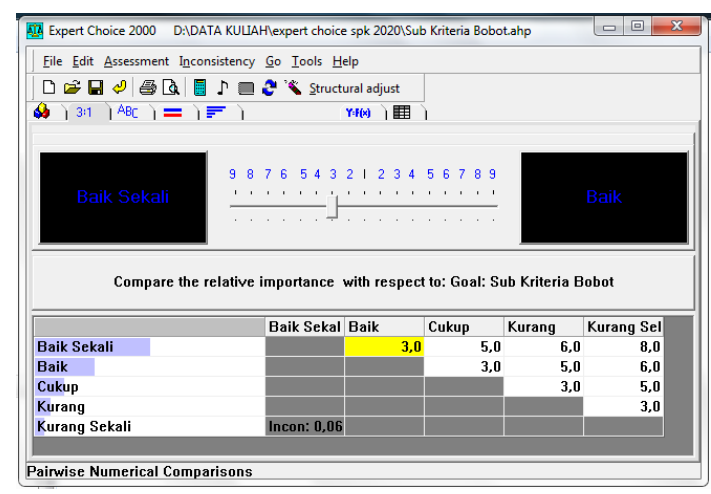

Gambar 10 Perbandingan subkriteria bobot

Perbandingan subkriteria bobot ini digunakan untuk menilai kriteria dan subkriteria yang ada. Semua kriteria dan subkriteri perlu dinilai dalam bentuk kualitatif yaitu Baik sekali (BS), Baik (B), Cukup (C), Kurang (K) dan Kurang Sekali (KS). Setelah nilai perbandingan dimasukkan maka konsisensi rasio yang didapatkan 0.06 .

3. Menghitung prioritas global

Proses perhitungan prioritas global dilakukan dengan cara weights pada setiap kriteria dikalikan dengan weights subkriteria dan dikalikan dengan weight pada subkriteria bobot.

Tabel 1 Prioritas Global

\begin{tabular}{|l|l|l|l|l|l|l|}
\hline & \multicolumn{4}{|c|}{$\mathrm{A}$} & \multicolumn{2}{|c|}{ B } \\
\cline { 2 - 8 } & A11 & A12 & A13 & A14 & B21 & B22 \\
\hline BS & 0.123 & 0.033 & 0.024 & 0.018 & 0.110 & 0.110 \\
\hline B & 0.064 & 0.017 & 0.013 & 0.010 & 0.058 & 0.077 \\
\hline S & 0.053 & 0.009 & 0.006 & 0.005 & 0.029 & 0.029 \\
\hline K & 0.003 & 0.004 & 0.003 & 0.002 & 0.015 & 0.015 \\
\hline KS & 0.009 & 0.002 & 0.002 & 0.001 & 0.008 & 0.008 \\
\hline
\end{tabular}


Tabel 1 yang menjelaskan prioritas global ini menunjukkan nilai dari subkriteria hasil kerja yang dikodekan (A11...A14) dan penguasaan kerja yang dikodekan (B21...B22). Masing-masing subkriteria memiliki nillai baik sekali, baik, sedang, kurang dan kurang sekali. Nilai tersebut dalam bentuk angka sehingga memudahkan untuk memberikan perhitungan proses penilaian pegawai.

Tabel 2 Prioritas Global (lanjutan)

\begin{tabular}{|l|l|l|l|l|l|l|l|}
\hline & \multicolumn{4}{|c|}{ C } & \multicolumn{3}{|c|}{ D } \\
\cline { 2 - 8 } & C31 & C32 & C33 & C34 & D41 & D42 & D43 \\
\hline BS & 0.047 & 0.017 & 0.008 & 0.004 & 0.029 & 0.009 & 0.004 \\
\hline B & 0.025 & 0.009 & 0.004 & 0.002 & 0.022 & 0.005 & 0.022 \\
\hline S & 0.013 & 0.005 & 0.002 & 0.001 & 0.008 & 0.002 & 0.001 \\
\hline K & 0.006 & 0.002 & 0.001 & 0.004 & 0.004 & 0.001 & 0.006 \\
\hline KS & 0.003 & 0.001 & 0.001 & 0.006 & 0.002 & 0.001 & 0.000 \\
\hline
\end{tabular}

Tabel 2 prioritas global menjelaskan nilai yang digunakan untuk kriteria Sikap kerja dan Disiplin. Masing-masing subkriteria yang ada memiliki nilai seperti yang ditampilkan pada tabel tersebut.

Tabel 3 Prioritas Global (lanjutan 1)

\begin{tabular}{|l|l|l|}
\hline \multirow{2}{*}{} & \multicolumn{2}{|c|}{ E } \\
\cline { 2 - 3 } & E51 & E52 \\
\hline BS & 0.029 & 0.036 \\
\hline B & 0.015 & 0.004 \\
\hline S & 0.008 & 0.002 \\
\hline K & 0.004 & 0.001 \\
\hline KS & 0.002 & 0.001 \\
\hline
\end{tabular}

Tabel 3 prioritas global (lanjutan 1) menjelaskan nilai kriteria penunjang (E). Kriteria tersebut memiliki 2 subkriteria. Jika Baik Sekali pada subkriteria 5S dan K3 maka nilai yang didapatkan (0.029)

4. Konversi nilai

Konversi nilai dilakukan untuk memudahkan proses perhitungan. Sebagai contoh jika pegawai nilai kualitas pada hasil kerja baik sekali maka angka yang diinput (0.033). untuk nilai yang baik disesuaikan dengan tabel prioritas yang sudah ada.

\subsection{Desain}

\subsubsection{Desain Logic}

Dalam usulan desain logic penelitian ini, diagram UML yang digunakan untuk menjelaskan sistem dengan Use Case. Use Case dijelaskan dengan Gambar 11.

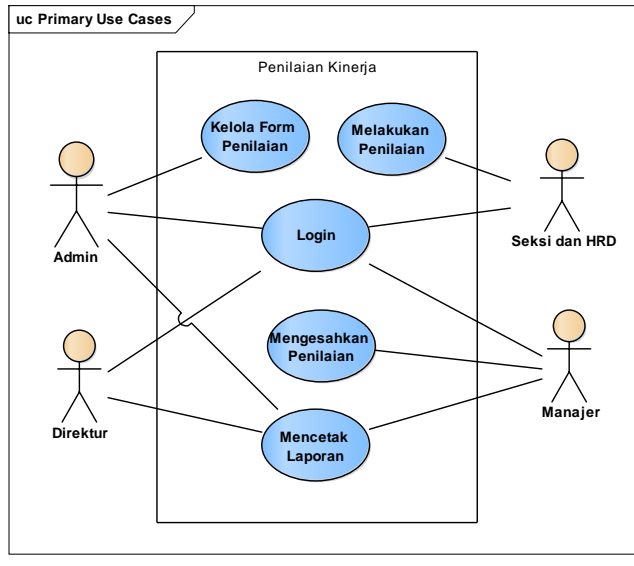

Gambar 11 Use Case Usulan Sistem

Dalam Gambar 11 tentang use case usulan sistem terdapat 4 aktor yang terdiri dari Admin, Seksi dan HRD, Manager dan Direktur.

\subsubsection{Desain Fisik}

Desain fisik ini menggambarkan usulan tampilan sebuah aplikasi berbasis web.

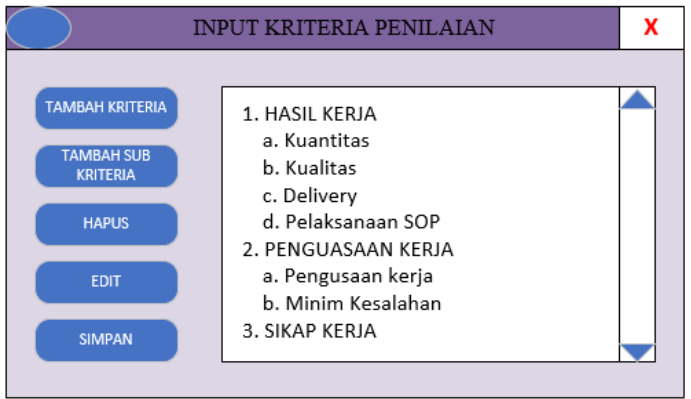

Gambar 12 Input kriteria penilaian

Gambar 12 tentang input kriteria penilaian menjelaskan bagaimana seorang admin dalam proses melakukan penambahan, pengeditan, penghapusan kriteria dan subkriteria.

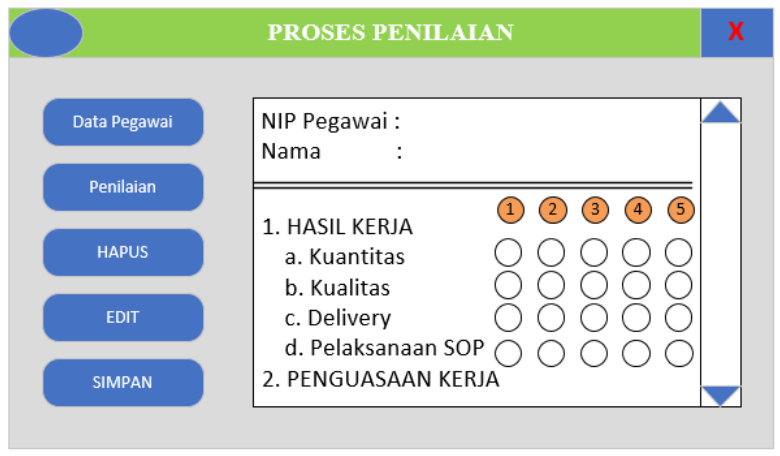

Gambar 13 Form Penilaian

Dalam form penilaian yang dijelaskan dengan Gambar 13 tentang form penilaian, menunjukkan 
bahwa penilai bisa dengan mudah melakukan proses penilaian. Penilaia tinggal klik lingkaranga yang ada nomor di atasnya 1, 2, 3, 4 dan 5.5 berarti baik sekali, 4 berarti baik, 3 artinya cukup, 2 kurang dan 1 memiliki makna kurang sekali.

\section{Kesimpulan}

Sistem pendukung keputusan penilaian kinerja ini mengusulkan untuk penambahan subkriteria dari kriteria sebelumnya yang sudah ada. Setelah dilakukan perhitungan dengan AHP maka nilai yang muncul untuk kriteria hasil kerja (A) pada subkriteria kuantitatif A11 dengan skor 0.123 , kualitatif A12 dengan skor 0.033 , delivery A13 dengan skor 0.024 dan pelaksanaan SOP A14 dengan skor 0.018. Skor tersebut untuk nilai Baik Sekali (BS). Untuk kriteria dan subkriteria yang lain juga memiliki skor yang berbeda2 sesuai dengan hasil hitungannya.

Penelitian ini dilakukan sampai dengan pembuatan desain logic dan desain fisik sehingga sangat memungkinkan untuk dikembangkan ke dalam sistem pendukung keputusan berbasis Web.

\section{Penelitian yang Akan Datang}

Penelitian yang sebaiknya dilakukan dari penelitian ini adalah membuat aplikasi berbasis web. Dengan aplikasi tersebut diharapkan SPK Penilaian Kinerja bisa memberikan dampak yang luar biasa bagi perusahaan.

\section{Referensi}

Haag, S dan Cummings, M.2013. Management Information System for The Information Age. McGraw-Hill/Irwin, 2013.

Hardianti, M. Hidayatullah, R. Pratiwi, F dan Hadiansa A. 2017. Sistem Penunjang Keputusan Penilaian Kinerja Pegawai Menggunakan Metode Analytical Hierarchy Proces (AHP). Jurnal Informatika, Manajemen dan Komputer. Vol. 9 No. 2. Desember 2017.

Liesnaningsih. Taufiq, R. Destriana, R dan Prayoga, A. 2020. Sistem Pendukung Keputusan Penerima Beasiswa Berbasis WEB Menggunakan Metode Simple Additive Weighting (SAW) pada Pondok Pesantren Daarul Ahsan. Jurnal Informatika Universitas Pamulang. Vol 5 No 1. 2020.

Mufizar, T. Susanto dan Nurjayanti, N. 2015. Sistem Pendukung Keputusan Penilaian Kinerja Guru di SDN Mohammad Toha Menggunakan Metode Analytical Hierarchy Process (AHP). Konferensi Nasional Sistem \& Informatika 2015. STMIK
STIKOM Bali, 9 - 10 Oktober 2015

Saefudin dan Wahyuningsih, S. 2014. Sistem Pendukung Keputusan untuk Penilaian Kinerja Pegawai Menggunakan Metode Analytical Hierarchy Process (AHP) pada RSUD Serang. Jurnal Sistem Informasi Vol.1 No. 1. 2014. ISSN: 2406-7768.

Sari, RE dan Saleh, A. 2014. Penilaian Kinerja Dosen Dengan Menggunakan Metode AHP (Studi Kasus: Di Stimik Potensi Utama Medan). Seminar Nasional Informatika 2014.

Septarini, RS. 2017. Penentuan Jumlah Produksi Shampo Dengan Fuzzy Inference System Sugeno: Studi Kasus PT. Guardian Pharmatama Tangerang. JIKA (Jurnal Informatika), Vol 1 No 2, September 2017.

Suherdi, R A. Taufiq, R dan Permana, AA.2018. Penerapan Metode AHP dalam Sistem Pendukung Keputusan Kenaikan Pangkat Pegawai Di Badan Kepegawaian Dan Pengembagan Sumber Daya Manusia Kota Tangerang," in SINTAK, 2018, pp. 522-528.

Taufiq, R dan Fahrozi, N.F. 2017, Perancangan Sistem Pendukung Keputusan (SPK) Pemilihan Kendaraan Alat Berat Tambang Batubara dengan Metode Analytical Hierarchy Process (AHP), Scientium: Jurnal Ilmiah Dewan Riset Daerah Banten, Vol. 3, No. 5, hh. 94-107.

Taufiq, R dan Mustofa, IS.2017. Perancangan Sistem Pendukung Keputusan Kejurusan Menggunakan Metode Simple Additive Weighting (Saw) Di Sma Negri 15 Tangerang," TI Atma Luhur, vol. IV, no. 1, pp. 103-114, 2017.

Taufiq, R dan Sugiharto, A 2011. The Decision Support System Design Of Employee Performance Appraisal Using Analytical Hierarchi Process (AHP) Method, Proceedings of The 1st International Conference on Information Systems For Business Competitiveness (ICISBC).

Taufiq, R. 2018. "Pengantar Sistem Informasi”. Jakarta. Mitra Wacana Media.

Taufiq, R. Magfiroh, DA. Yusuf, D dan Yulianti.2020. Sistem Informasi Pembayaran Sumbangan Pembinaan Pendidikan (SPP) di SMK Avicena Rajeg. Jurnal Teknologi Sistem Informasi dan Aplikasi. Vol. 3 No. 1, Januari 2020. Hal 15-21.

Turban, J. Aronson, E dan Liang, TP. 2005. Decision Support Systems and Intelligent Systems, Decis. Support Syst. Intell. Syst., vol. 7, p. 867, 2005.

Umar, R. Fadlil, A dan Yuminah. 2018. Sistem Pendukung Keputusan dengan Metode AHP untuk Penilaian Kompetensi Soft Skill Karyawan. Jurnal ilmu Komputer dan Informatika. Vol. 4 No. 1. Juni 2018 